\title{
The Impact of Customer Satisfaction and Switching Barriers on Customer Loyalty in Pakistani Mobile Telecommunication Services
}

\author{
Niaz Ahmed Bhutto \\ Associate Professor, Sukkur Institute of Business Administration \\ Air Port Road Sukkur, Pakistan \\ Sarwar M. Azhar \\ Professor, University of Management and Technology \\ Lahore \\ Irshad Hussain Sarki \\ (Corresponding author) \\ Research Scholar, Sukkur Institute of Business Administration \\ Air Port Road Sukkur, Pakistan \\ E-mail: Ih_sarki@iba-suk.edu.pk \\ Rafique Ahmed Khuhro \\ Sukkur Institute of Business Administration \\ Air Port Road Sukkur, Pakistan \\ Imran Arshaad \\ Research Scholar, Sukkur Institute of Business Administration \\ Air Port Road Sukkur, Pakistan
}

Received: June 17, $2012 \quad$ Accepted: September 2, 2012 Published: October 1, 2012 doi:10.5296/jmr.v4i4.1963 URL: http://dx.doi.org/10.5296/jmr.v4i4.1963 


\begin{abstract}
The successes of the firms depend on creating high customer loyalty by adopting appropriate strategies. In response, the industry is shifting its strategic focus away from attracting only new customers by offering competitive prices and packages, towards retaining existing customers through creating customer loyalty. This study aims to investigate the effects of customer satisfaction and switching barriers on customer loyalty. The data is collected by questionnaire based survey using simple convenient sampling technique and the target population includes all the current users of mobile telecommunication services. Multiple regression method is used to test the impact of customer satisfaction determinants and switching barrier on customer loyalty. The result shows that call quality and customer support have significance relationships with customer loyalty. A one way ANOVA test was also used gender differences among customer satisfaction and switching barriers in Pakistani mobile telecommunication services. Findings of the study may be useful for strategists and policy makers in telecom industry and the results can be generalized to the industries.
\end{abstract}

Keywords: Service Quality, Switching Barriers, Customer Satisfaction, Telecom Industry, Pakistan 


\section{Introduction}

A lot of studies have been done to find out the effective means of generating customer loyalty through satisfying a customer and switching barrier (Min \&Wan, 2009; Kim et al., 2004). In one study Pollack (2009) has briefly explained that different factors of service quality which are determinants of customer satisfaction, lead to customer loyalty which is beneficial for the organization in making profit. A highly satisfied customer likes to remain with the existing company. But some researchers argues that customer satisfaction is not enough for the loyalty and sometimes it fails in providing expected results, in this situation switching barrier plays an important role in the influencing loyalty (Jones, Mothersbahgh \& Betty,2002).

The Mobile telecommunication services in Pakistan are working intensive competition. Despite the slowdown in the economy of Pakistan mobile phone service providers continue their network expansion by extending services to different rural areas resulting in the growth in their subscribers' base. According to PTA's report market share of Mobilink is $32.47 \%$., leading the mobile market of Pakistan, The market share of other mobile operators are Telenor $23.99 \%$, Ufone $19.71 \%$, Warid $17.07 \%$ and Zong $6.67 \%$ respectively. The mobile telecommunication industry remains on the top in the current year in terms of revenue generation and its revenue increased by $11 \%$ and the subscription base grew by $5 \%$ in comparison to the last year (PTA, 2010). It means that mobile telecom industry is still growing though average a slower rate.

Every company is trying to capture the customers of other operators through attractive packages and marketing campaigns. It is usually difficult for the mobile network operators to retain their customers (Shin et al, 2004). In such a scenario it is necessary for the operators to make a strong bond with the customers through brand loyalty. A highly satisfied customer likes to remain with the current company. But some researchers argue that customer satisfaction is not enough for the loyalty and sometimes it fails in providing expected results. In this situation switching barrier plays an important role in the influencing loyalty (Jones, Mothersbahgh \& Betty, 2002).

On the regional level several studies have been conducted on the antecedents of customer satisfaction (Ali et al., 2010; khan, 2010). However, these studies have mainly focused on exploring the impact of customer satisfaction and service quality respectively on the retention of the customers; but there is no such study that has explained the impact of customer satisfaction and switching barriers on Pakistani mobile telecommunication services. So it becomes necessary to explain that how customer satisfaction and switching barriers increases the customer loyalty in the Pakistani mobile telecommunication services through this study.

The objectives of this study are,

1- To predict the impact of customer satisfaction and switching barrier on customer loyalty in Pakistani mobile telecommunication services.

2- To analyze the gender differences among customers satisfaction and switching barriers in Pakistani mobile telecommunication services. 


\section{Macrothink Institute ${ }^{\mathrm{TM}}$}

This study will be beneficial for the Pakistani mobile telecommunication services providers in order to enhance the loyalty of customers with them. This study will explain the impact of customer satisfaction and switching barriers on the customer loyalty in Pakistani mobile telecommunication services. This study will be beneficial for the marketers while making strategies to make the potential customers loyal by fulfilling the needs and wants of customers properly. This study will also be beneficial for the students and instructors while discussing the concepts of customer satisfaction, switching barriers and customer loyalty in their classrooms. Moreover this study will provide recommendations for the future research of marketing.

\section{Literature Review}

\section{Customer loyalty}

Customer loyalty is such a dependent variable that is used by many researchers (Reichheld \& Schefter, 2000). Customer loyalty in the context of mobile telecommunication is defined as the intension of a customer to stay with the current operator regardless of marketing promotions and situational influences that causes switching barriers (Oliver, 1999). Many researchers argued that customer loyalty can be generated by delighting the customers (Lee, Lee \& Feick, 2oo1; Oliver, 1999) and this can be achieved through providing superior value and quality products (Parasuraman \&Grewal, 2000). In business, customer loyalty is considered as one of the competitive and a significant factor for success (Rreichheld \& Schefter, 2000).

According to Oliver (1999) there are four stages of loyalty development; these are cognitive, conative, affective and action loyalty. Cognitive loyalty is formed on the Bases of knowledge and information, affective loyalty is formed on the basis of collective experiences; conative loyalty refers to the behavioral intention to purchase and action loyalty. This repeat purchase behavior is in the interest of the company in terms of providing firm improved profitability. There are three approaches to study customer loyalty. These include behavioral approach, attitudinal approach and integrated approach (Oh, 1995). The first describes the customer's permanence of past purchases, second explains the sense of good will of customers and third is a combination of both behavioral and attitudinal.

A highly satisfied customer likes to remain with the current company. But some researchers argue that customer satisfaction is not enough for the loyalty and sometimes it fails in providing expected results. In this situation switching barrier plays an important role in the influencing loyalty (Jones, Mothersbahgh \& Betty, 2002).

Switching barriers play an important role in customer loyalty when the level of satisfaction is the same for all the operating companies (Gerpott et al., 2001; Kim et al., 2004).

In other words companies' survival and growth, customer loyalty plays a significant role by retaining existing customers during intensive competition (Ahmad \& Buttle, 2002).

\section{Customer Satisfaction}

Many researchers in the literature argue that higher level of customer satisfaction leads to 
higher level of customer loyalty (Yang \&Petersen 2004; Lee et al., 2001).Customer satisfaction is defined as the fulfillment of customer's expectations and perceptions (Moshavi, 2004; Oliver, 1999). In the following section the paper focuses on literature on customer satisfaction that is significantly relevant to the mobile telecommunication services. The paper does this while acknowledging that a vast body of literature exists that is targeted in other areas of service industry and businesses.

Lee et al (2001) described customer satisfaction in three groups of core services, value added services and pricing plan but Lim et al., (2006) on the other hand proposed several dimensions of customer satisfaction such as customer services, locator services, pricing plans ,network quality, entertainment services and SMS services.

Research done by the Vividence Corporation (2002) found that $35 \%$ of the mobile customers switch to other operator, $28 \%$ due to the better service. But some researchers contritely argue that switching of customers to other services is mainly due to better price along with other factors (Kim et al., 2004; Shin et al., 2004).

Customer's own perception about the service quality is the main antecedent that explains customer satisfaction (Zeithamal \& Bitner, 1996). Service quality is defined as satisfaction or dissatisfaction formed after the use of service (Parasuraman, Zeithmal \& Berry, 1998).

In the mobile telecommunication service provider industry many researchers used call quality, mobile devices, value added services, convenience in using, pricing structure and customer support to measure service quality (Kim et al 2004; Gerpott, et al., 2001; and Freick, 2001) which leads to customer loyalty and prices profitability (Pollack, 2009).

\section{Switching Barriers}

Fornell (1992) defines switching barrier as the difficulty in changing the service from one operator to another operator by a dissatisfied customer. Literature informs us that higher the switching barrier, the more the customer will remain with the existing operator. Studies have explained that switching barrier is made up of the switching cost, alternative attractiveness and interpersonal relationship.

Switching cost is defined as the cost incurred when switching from one operator to another operator (Porter, 2008).Switching cost means the cost that a customer has to pay while switching away from the current product and this cost depends on the type of product in question. The cost are incurred in terms of time, money wasted and also includes intangible psychological cost (Dick and Basu ,1994 \& Aidin, 2005).In terms of the mobile telecommunication services, switching cost is defined as the loss cost, move in cost and adoption cost (Kim et al., 2004).

Some scholars have explained that there is a significant effect of switching cost on customer loyalty (Sharma and Patterson 2000, Sharma 2003) while other says that there is a moderating effect of switching cost on customer loyalty (Lee et al., 2001; Oliver 1999, Jones at al. 2000, Bansal and Taylor 2004). Contrarily Yang \& Peterson (2004) found that no direct or moderating effect of switching cost on customer loyalty. After further analysis they, 
however found that there is a relationship between switching cost and customer loyalty if the customer satisfaction is above the average.

Alternative attractiveness means the perception of the customers about the competing company available in the market (Jones et al., 2000). While Kim et al. (2004) described alternative attractiveness as the perception of customer about the reputation image and service quality of another operator.

There are lot of studies on the interaction of alternative attractiveness and customer loyalty. Some of them find negative relationship between the two (Bansal and Taylor, 2004; Yim et al., 2007), other find some interaction effect between them (Jones at al. 2000, Sharma and Patterson 2000, Sharma 2003), while Lee et al. (2008) wrote that there is no effect between customer loyalty and alternative attractiveness.

Interpersonal relationship is defined as the relationship that shows itself as care, trust and communication between customer and operator (Gremler, 1995). Many customers wish to have such relationship with the companies and these relationships increase the barriers to switching in the mobile telecommunication service industry.

\section{Methodology}

This research is conducted to measure the affect of customer satisfaction and switching barrier on customer loyalty in Pakistani mobile telecommunication services. This is causal comparative study and aims to study the effects of customer satisfaction and switching barrier on loyalty of mobile phone users. The measurement items used for collecting the data about variables were taken from Kim et al. (2004). The same scale was used by Ali et al. (2010) for measuring the determinants of consumer satisfaction in cellular industry of Pakistan. The variables used for measuring satisfaction were call quality, pricing structure, and value added services, convenience in procedure and customer support. And variables used for measuring the switching barrier are switching cost, alternative attractiveness and interpersonal relationships.

Convenient sampling was used for this research and the respondents were the students of Shah Abdul Latif University, Sukkur IBA, and University of Sindh, The reason behind focusing on university students for the collection of data is that young students pay more attention towards the promotional activities and also students are the main target market for the service providers. The number of questionnaire distributed were 300 of which 285 questionnaires were returned properly filled while 31 questionnaires were partially completed and thus rejected leaving 254 useable questionnaires for this study. SPSS 16 is used for the analyses of the data and testing hypothesis.

The sampling for this research was collected from universities. 300 survey forms were distributed among the respondents and 254 or $84 \%$ were collected back. There were $74.8 \%$ males and $25.2 \%$ females. The $67.3 \%$ respondents of the study were form the urban area and $32.7 \%$ were from the rural areas. The sample characteristics of the five mobile telecommunication services were as Mobilink $16.95 \%$, Ufone $38.18 \%$, Telenor $20.47 \%$ Warid $6.67 \%$ and Zong $17.71 \%$. The percentage of Ufone is greater than other operators 
because it targeting the youth by their attractive call and SMS packages. The cross tabulation of all measures by demographics are shown in the table 1 .

Table 1.Cross-table of measures by demographics (mean \& standard deviation)

What's your age?

\begin{tabular}{|c|c|c|c|c|c|c|c|c|}
\hline & \multicolumn{2}{|c|}{ 15-19 Years } & \multicolumn{2}{|c|}{ 20-29 years } & \multicolumn{2}{|c|}{$30-39$ years } & \multicolumn{2}{|c|}{40 OR MORE } \\
\hline & Mea & Standard & & Standard & & Standard & & Standard \\
\hline & $\mathrm{n}$ & Deviation & Mean & Deviation & Mean & Deviation & Mean & Deviation \\
\hline Call quality & 3.22 & .76 & 3.28 & .79 & 2.98 & .83 & 3.00 & .00 \\
\hline Price structure & 3.27 & .79 & 3.34 & .53 & 3.40 & .78 & 4.00 & .47 \\
\hline Value added & 3.39 & .71 & 3.36 & .69 & 3.42 & .66 & 3.50 & .71 \\
\hline $\begin{array}{l}\text { Convenient of } \\
\text { use }\end{array}$ & 3.35 & .52 & 3.40 & .72 & 3.50 & .76 & 3.50 & .71 \\
\hline $\begin{array}{l}\text { Customer } \\
\text { support }\end{array}$ & 3.40 & .71 & 3.24 & .75 & 3.63 & .58 & 3.50 & .71 \\
\hline
\end{tabular}

Switching

Barrier

\begin{tabular}{lcccccccc} 
Loss cost & 3.36 & .99 & 3.03 & 1.10 & 3.05 & .76 & 4.00 & 1.41 \\
Adoption cost & 3.13 & .78 & 3.14 & .77 & 3.25 & .50 & 3.00 & .00 \\
$\begin{array}{l}\text { Move in cost } \\
\begin{array}{l}\text { Alternative } \\
\text { carrier's }\end{array}\end{array}$ & 3.39 & .90 & 3.26 & .78 & 3.20 & .80 & 2.50 & 2.12 \\
$\begin{array}{l}\text { image } \\
\begin{array}{l}\text { Interpersonal } \\
\text { relationship }\end{array}\end{array}$ & 3.44 & .59 & 3.24 & .69 & 3.30 & .74 & 2.17 & 1.18 \\
$\begin{array}{l}\text { Customer } \\
\text { loyalty }\end{array}$ & 3.68 & .58 & 3.58 & .65 & 3.52 & .77 & 3.25 & .35 \\
\hline
\end{tabular}

\section{Results and Discussion}

\section{Reliability}

Reliability is defined as the stability of outcomes when the purpose of research is measured repeatedly (Kim et al., 2004).It is usually measured by Cronbach's alpha methodology. Cronbach's alpha measures the average of items of variables and their correlation and results are considered reliable if it is more than 0.5. In this research Cronbach's alpha was almost $81.6 \%$.

One way ANOVA test was used to understand the gender differences among customer 
satisfaction and switching barriers in Pakistani mobile telecommunication services as indicated in table 2.

Table 2. ANOVA (Gender Differences among customer satisfaction and switching barriers in Pakistani mobile telecommunication services)

\begin{tabular}{llll}
\hline Customer's satisfaction and & & & \\
Switching Barriers & $F$ & $d f$ & Sig. \\
\hline Call quality & 0.010 & 1 & 0.919 \\
Price structure & 2.998 & 1 & $0.085^{*}$ \\
Value added & 0.508 & 1 & 0.477 \\
Convenient of use & 1.207 & 1 & 0.273 \\
Customer support & 1.344 & 1 & 0.247 \\
Service quality & 0.216 & 1 & 0.643 \\
Loss cost & 0.096 & 1 & 0.757 \\
Adoption cost & 1.229 & 1 & 0.269 \\
Move in cost & 2.050 & 1 & $0.053^{*}$ \\
Alternative carrier's image & 0.782 & 1 & 0.377 \\
Interpersonal relationship & 1.018 & 1 & 0.314 \\
\hline
\end{tabular}

* Significant at 0.10 level (two tailed).

The results indicate that there exist significant differences between male and female in price structure construct of customer satisfaction in Pakistani mobile telecommunication services which is significant at $p<.10$. The results also indicate that there exist significant differences between male and female in move in cost construct of switching barriers in Pakistani mobile telecommunication services which is significant at $p<.10$. The results also indicate that there exist no significant differences between the call quality, value added, convenient, customer support, service quality, loss cost, alternative carrier's image, and interpersonal relationship constructs of customer satisfaction and switching barriers in Pakistani mobile telecommunication services.

Multiple regression analysis was used to predict the affect customer satisfaction and switching barrier on customer loyalty in Pakistani mobile telecommunication services. For this study the customer loyalty was taken as a dependent variable and the constructs of customer satisfaction and switching barrier such call quality, price structure ,value added, convenient, customer support, service quality, loss cost, move in cost, alternative carrier's image, and interpersonal relationship were taken as the independent variables. 


\section{Macrothink Institute ${ }^{\mathrm{TM}}$}

Table 3.Regression Analysis of customer satisfaction and switching barrier on customer loyalty in Pakistani mobile telecommunication services

\begin{tabular}{lccc}
\hline & \multicolumn{3}{l}{ Standardized coefficients } \\
\cline { 3 - 4 } Customer satisfaction & and & & \\
Switching Barriers & & 0.259 & Sig. \\
\hline Constant & 0.355 & 6.199 & 0.796 \\
Call quality & 0.058 & 1.004 & 0.000 \\
Price structure & 0.070 & 1.011 & 0.316 \\
Value added & 0.057 & 0.956 & 0.313 \\
Convenient of use & 0.394 & 7.252 & 0.340 \\
Customer support & 0.064 & 0.995 & 0.000 \\
Alternative carrier's image & 0.015 & 0.254 & 0.321 \\
Interpersonal relationship & -0.062 & -0.985 & 0.799 \\
Switching cost & & & 0.325 \\
& .420 & $\mathrm{~F}=22.032$ & $\mathrm{P} \leq .000$ \\
$\mathrm{R}^{2}$ & .401 & & \\
Adjusted $\mathrm{R}^{2}$ & & & \\
\hline
\end{tabular}

Note: Dependent Variable: customer loyalty

The results suggest that customer loyalty is predicted by the customer satisfaction constructs such as call quality, and customer support. The results in table 3 are indicating the strength of call quality $(\beta=0.355 ; P<0.000)$, customer support $(\beta=0.394 ; P<0.000)$ in predicting the customer loyalty in Pakistani mobile telecommunication services.

This explains the fact that call quality of any mobile telecommunication service has a strong association with the loyalty of the customer and also the same result was found by Kem et al (2004) and Ali et al (2010) in their studies. In the mobile telecommunication service provider industry many researchers used call quality along with other constructs to measure satisfaction (Kim et al 2004; Gerpott, et al., 2001; and Freick, 2001) which leads to customer satisfaction and prices profitability (Pollack, 2009).

\section{Conclusion}

The primarily purpose of this study was to analyze the effect of customer satisfaction and switching barriers on customer loyalty and their role in increasing the customer loyalty in Pakistan mobile telecommunication services. On the basis of the results of this study we summarized the conclusion as,

First the study has found that that there exist significant differences between male and female in price structure construct of customer satisfaction in Pakistani mobile telecommunication services. The results indicate that there exist significant differences between male and female 
in move in cost construct of switching barriers in Pakistani mobile telecommunication services.

Second the study suggested that customer loyalty is predicted by the customer satisfaction constructs such as call quality, and customer support. The results are indicating that the determinants of customer satisfaction such as call quality and customer support has the strong impact on customer loyalty. This is all due to that companies have focused more on the service quality for last two years (PTA, 2010). The study also has showed that switching barriers such as switching cost, alternative carrier's image and interpersonal relationship have no significant impact on customer loyalty. This is due to that all the mobile phones companies operating in Pakistan are not focusing on such kind of barriers. After the popularity of MNP in Pakistan all companies reduced such kind of barrier to attract the customers of the other mobile phone operators.

The findings of this study will be helpful to the mobile telecommunication services in making future decisions.

\section{Limitations}

This study has the following limitations:

First the data was collected from the students of different universities, so all the results obtained from this study are not the representative of the whole population of Pakistan. Second these all variables are not enough to describe the future direction for the mobile telecommunication services operating in Pakistan, there may be some other variables like as demographic, cultural ,technological, personality and psychological which can play a significant role in the enhancement of satisfaction and switching barrier and their association with customer loyalty.

\section{References}

Ahmad, R., \& Buttle, F. (2002). Customer retention management: A reflection of theory and practice. Marketing Intelligence and Planning, 20(3), 149-161.

http://dx.doi.org/10.1108/02634500210428003

Ali, I., Ali, J. F., Rehman, K., Yilmaz, A. K., Safwan, N. \& Afzal, H. (2010). Determinants of Consumer Retention in Cellular Industry Of Pakistan. African Journal of Business Management, 4(12), 2402-2408.

Bansal, H.S., Taylor, S.F., \& James, Y. (2005). Migrating to new service providers: Toward a unifying framework of consumers' switching behaviors. Journal of the Academy of Marketing Science,33(1), 96-115. http://dx.doi.org/10.1177/0092070304267928

Brown, T. J., Barry, T. E., Dacin, P. A., \& Gunst, R. F. (2005). Spreading the word: Investigating antecedents of consumers' positive word-of-mouth intentions and behaviors in a retailing context. Journal of the Academy of Marketing Science, 33, 123-138. http://dx.doi.org/10.1177/0092070304268417

Colgate, M., \& Lang, B. (2001). Switching barriers in consumer markets: An investigation of 
the financial services industry. Journal of Consumer Marketing, 18(4), 323-347. http://dx.doi.org/10.1108/07363760110393001

Dick, A. S., \& Basu, K. (1994). Customer loyalty: Toward an integrated conceptual framework. Journal of the Academy of Marketing Science, 22, 99-113. http://dx.doi.org/10.1177/0092070394222001

Fornell, C. (1992). A national customer satisfaction barometer: The Swedish experience. Journal of Marketing,56, 6-21.http://dx.doi.org/10.2307/1252129

Gerpott, T. J., Rams, W., \& Schindler, A. (2001). Customer Retention, Loyalty, and Satisfaction in the German Mobile Cellular Telecommunications Market. Telecommunications Policy, 25, 249-269.http://dx.doi.org/10.1016/S0308-5961(00)00097-5

Gremler, D. D. (1995). The effect of satisfaction, switching costs, and interpersonal bonds on service loyalty. Unpublished dissertation, Arizona State University.

Jones, M. A., Mothersbaugh, D. L., \& Betty, S. E. (2002). Why customers stay: Measuring the underlying dimensions of services switching costs and managing their differential strategic outcomes. Journal of Business Research, 55, 441-450.http://dx.doi.org/10.1016/S0148-2963(00)00168-5

Khan , M. A. (2010). An empirical assessment of service quality of cellular mobile telephone operators in Pakistan. Asian Social sciences, 6(10),164-177.

Kim, M.K., Park, M. C., Jeong, D. H. (2004). The Effects of Customer Satisfaction and Switching Barrier on Customer Loyalty in Korean Mobile Telecommunication Services. Telecommunications Policy, 28, 145-159.http://dx.doi.org/10.1016/j.telpol.2003.12.003

Lee, J., Lee, J., \& Feick, L. (2001). The impact of switching costs on the customer satisfaction loyalty link: Mobile phone service in France. Journal of Services Marketing 15(1), 35-48.http://dx.doi.org/10.1108/08876040110381463

Lim, H., Widdows, R., Park, J. (2006). M-loyalty: winning strategies for mobile carriers. Journal of Consumer $\quad$ Marketing,23(4), 208-218. http://dx.doi.org/10.1108/07363760610674338

Min, D., and Wan, L. (2009). Switching factors of mobile customers in Korea. Journal of social sciences, $1,105-120$.

Mittal, V., \& Kamakura, W. A. (2001). Satisfaction, repurchases intent, and repurchases behavior: Investigating the moderating effect of customer characteristics. Journal of Marketing Research, 38, 131-142.http://dx.doi.org/10.1509/jmkr.38.1.131.18832

Moshavi, D. (2004). He said, she said: Gender bias and customer satisfaction with phone-based service encounters. Journal of Applied Social Psychology,34, 162-176.http://dx.doi.org/10.1111/j.1559-1816.2004.tb02542.x

Murray, K. B. (1991). A test of services marketing theory: Consumer information acquisition activities. Journal of Marketing, 55, 10-25.http://dx.doi.org/10.2307/1252200 
Oh, H. C. (1995). An empirical study of the relationship between restaurant image and customer loyalty. Unpublished Ph. D. Dissertation, Virginia Polytechnic Institute and State University.

Oliver, R. L. (1999). Whence customer loyalty? Journal of Marketing, 63, 33-44.http://dx.doi.org/10.2307/1252099

Parasuraman, A., \& Grewal, D. (2000). The impact of technology on the quality-valueloyalty chain: A research agenda. Journal of Academic of Marketing Science, 28, 168-174.http://dx.doi.org/10.1177/0092070300281015

Parasuraman, A., Zeithamal, V. A., \& Berry, L. L. (1988).SERVQUAL: A multiple-item scale for measuring consumer perceptions of service quality. Journal of Retailing, 64, 12-40.

Pollack, B.L. (2009). Linking the hierarchal service quality model to customer satisfaction and loyalty. Journal of service Marketing, 23(1), 42-50.

http://dx.doi.org/10.1108/08876040910933084

Porter, M.E. (2008). The five competitive forces that shape strategy. Harvard Business Review, 86(1), 79-93.

Reichheld, F.F., \& Schefter, P. (2000). E-loyalty: Your secret weapon on the Web. Harvard Business Review, 78, 105-113.

Sharma, N. (2003). The role of pure and quasi-moderators in services: An empirical investigation of ongoing customer-service-provider relationships. Journal of Retailing and Consumer Services, 10(4), 253-262. http://dx.doi.org/10.1016/S0969-6989(02)00020-6

Sharma, N., \& Patterson, P. G. (2000). Switching costs, alternative attractiveness and experience as moderators of relationship commitment in professional, consumer services. International Journal of Service Industry Management, 11(5), 470-490. http://dx.doi.org/10.1108/09564230010360182

Shin, H. W., and Sohn, S. Y. (2004). Multi-Attribute Scoring Method for Mobile Telecommunication Subscribers. Expert Systems with Applications, 26, 363-368. http://dx.doi.org/10.1016/j.eswa.2003.09.013

Vividence (2005). Web Strategies to Attract and Retain Telecommunications Customers, 2005, from http://www.ividence.com

www.pta.gov.pk

Yang, Z. L., \& Peterson, R. T. (2004). Customer perceived value, satisfaction and loyalty: The role of switching costs."Journal of Psychology \& Marketing, 21(10), 799-822.

Yim, C. K., Chan, K. W., \& Hung, K. (2007). Multiple reference effects in service evaluations: Roles of alternative attractiveness and self-image congruity. Journal of Retailing,83(1), 147-157. http://dx.doi.org/10.1016/j.jretai.2006.10.011

Zeithamal, A., \&Bitner, M. J. (1996). Customer contribution and roles in service delivery. International Journal of Service Marketing, 8(3), 193-205. 